\title{
Simple Spectrophotometric Methods for the Determination of Two Phosphodiesterase Type 5-Inhibitors in Pure and Tablets Dosage Forms Using $N$-Bromosuccinimide as an Oxidant
}

\author{
EMAN M HAFEZ ${ }^{1}$, RAGAA EL SHIEKH ${ }^{1}$, ALAA S AMIN ${ }^{2}$ and AYMAN A GOUDA ${ }^{1 *}$ \\ ${ }^{1}$ Chemistry Department, Faculty of Sciences, Zagazig University, Zagazig, Egypt \\ ${ }^{2}$ Chemistry Department, Faculty of Sciences, Benha University, Benha, Egypt \\ aymangouda77@gmail.com
}

Received 21 May 2016 / Accepted 4 June 2016

\begin{abstract}
Three simple, sensitive spectrophotometric methods were proposed for the quantification of two phosphodiesterase type 5-inhibitors; vardenafil $\mathrm{HCl}$ (VARD) and tadalafil (TDF) in pure forms as well as in tablets dosage forms. The methods use $N$-bromosuccinimide (NBS) as an analytical reagent and three dyes, amaranth methylene blue, and indigocarmine or orange $\mathrm{G}$, as auxiliary reagents. The three methods are based on oxidation reaction of VARD or TDF with a known excess of $\mathrm{N}$-bromosuccinimide (NBS) in acid medium, followed by determination of unreacted NBS by the reaction with a fixed amount of three dyes, amaranth, methylene blue and indigocarmineor orange $\mathrm{G}$ followed by the measurement of the absorbance at 520, 664 and 610 or $478 \mathrm{~nm}$, respectively. Under the optimum conditions, the three methods are applicable over the concentration ranges of 1.0-16, 1.0-12 and 1.0-10 $\mu \mathrm{gmL}^{-1}$ for VARD using amaranth methylene blue and indigocarmine methods, respectively and 2.0-12, 2.0-15 and 1.0-10 $\mu \mathrm{gmL}^{-1}$ for TDF using amaranth methylene blue and orange $\mathrm{G}$, respectively. The molar absorptivities, Sandell's sensitivity values, correlation coefficients, limits of detection and quantification are reported. Intra-day and inter-day accuracy and precision of the methods have been evaluated. No interference was observed from the common tablet excipients. The methods were successfully applied to the assay of VARD and TDF in tablets preparations and the results were statistically compared with those of the reference methods by applying Student's $t$-test and $F$-test. The reliability of the methods was further ascertained by performing recovery studies using the standard addition method.
\end{abstract}

Keywords: Spectrophotometry, VardenafilHCl, Tadalafil, $N$-bromosuccinimide, Tablets

\section{Introduction}

Vardenafilhydrochloride (VARD)is designated chemically aspiperazine, 1-[[3-(1,4-dihydro5-methyl-4-oxo-7-propylimidazo[5,1-f] [1,2,4]triazin-2-yl)-4-ethoxy-phenyl] sulfonyl]-4ethyl-, monohydrochlorideand tadalafil(TDF) is designated chemically as (6R-trans)-6-(1,3benzodioxol-5-yl)- 2,3,6,7,12,12a-hexahydro-2-methyl-pyrazino [1', 2':1,6] pyrido[3,4-b]indole- 
1,4-dione (Figure 1). VARD and TDF are widely used as a selective phosphodiesterase type 5 - inhibitor (PDE5) in the management of erectile dysfunction ${ }^{1,2}$. Extensive literature survey revealed that the determination of VARD and TDF in pure and dosage forms are not official in any of the pharmacopoeias and therefore, require much more investigation.

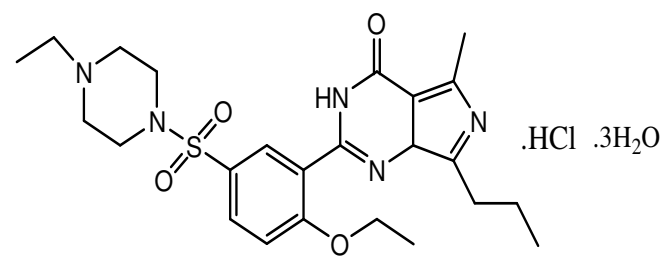

Vardenafil hydrochloride (VARD)

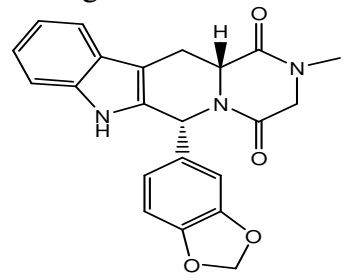

Tadalafil (TDF)

Figure 1. The chemical structure of vardenafil HCl (VARD) and tadalafil (TDF)

Few reports for the determination of VARD in pure, tablet dosage forms and biological fluids have been developed with the help of a variety of analytical tools including high performance liquid chromatography (HPLC) $)^{3-12}$, gas chromatography ${ }^{13,14}$, capillary electrophoresis $^{15,16}$, electrochemical methods ${ }^{17,18}$ and atomic emission spectrometry ${ }^{19-21}$. Several analytical methods have been reported for the estimation of TDF in biological fluids or pharmaceutical dosage forms include HPLC $^{22-34}$, liquid chromatography-tandem mass spectrometry with electrospray ionization ${ }^{35-37}$, micellar electrokinetic capillary chromatography ${ }^{38}$ and atomic emission spectrometry ${ }^{20,21}$.

All the above methods developed for the quantification of VARD and TDF employed complex analytical instruments for their estimation mainly in bulk drug powders, tablet dosage forms and biological fluids. However, most of these methods are complex, require expensive experimental setup and skilled personnel, suffer from time-consuming procedures, and are inaccessible to many laboratories in developing and under developed nations. In contrast, visible spectrophotometry is considered as the most convenient analytical technique in most quality control and clinical laboratories, hospitals and pharmaceutical industries for the assay of different classes of drugs in pure, pharmaceutical formulations and in biological samples, due to its simplicity and reasonable sensitivity with significant economic advantages.

To the best of our knowledge, there are some methods have been reported for the quantification of VARD and TDF in commercial dosage forms using a spectrophotometric technique $^{38-50}$ (Table 1). However, these previously reported methods suffer from one or the other disadvantage such as poor sensitivity, depending on critical experimental variables, few methods require a rigid $\mathrm{pH}$ control and tedious and time consuming liquid-liquid extraction step; some other methods have a relatively narrow dynamic linear range, involve a heating step, and/or use of expensive reagent or large amounts of organic solvents. For these reasons, it was worthwhile to develop a new simple, cost effective and selective spectrophotometric method for the determination of VARD and TDF their pharmaceutical dosage forms.

From the foregoing paragraphs, it is clear that $N$-bromosuccinimide (NBS) despite its strong oxidizing power, versatility and high oxidation potential and stability in solution has not been applied for the assay of VARD and TDF in pure forms and tablets.

The present investigation aims to develop for the first time sensitive and cost-effective methods for the determination of VARD and TDF in pure and dosage forms using spectrophotometric techniques. The methods employ $N$-bromosuccinimide which acts as brominating agent and four dyes; amaranth, methylene blue indigocarmine or orange $\mathrm{G}$, as auxiliary chromogenic reagents. 
Table 1. Comparison between the report spectrophotometric method for determination of VARD and TDF 
The proposed methods have been demonstrated to be superior to the reported methods with respect to speed, simplicity, sensitivity, being accurate and precise, cost effectiveness, eco-friendliness and can be adopted by the pharmaceutical laboratories for industrial quality control.

\section{Experimental}

All absorption spectra were made using Varian UV-Vis spectrophotometer (Cary 100 Conc., Australia) equipped with $10 \mathrm{~mm}$ quartz cell was used for absorbance measurements. This spectrophotometer has a wavelength accuracy of $\pm 0.2 \mathrm{~nm}$ with a scanning speed of $200 \mathrm{~nm} / \mathrm{min}$ and a bandwidth of $2.0 \mathrm{~nm}$ in the wavelength range of $200-900 \mathrm{~nm}$.

\section{Materials and reagents}

All chemicals, solvents and reagents used in this work were of analytical reagent or pharmaceutical grade and all solutions were prepared fresh daily. Bidistilled water was used throughout the investigation.

\section{Reference standard of pure drugs}

Pharmaceutical grade VARD and TDF working standard was kindly supplied by their respective manufactures in Egypt, without any conflicts of interests in our submitted paper.

\section{Pharmaceutical formulations}

The following tablets were purchased from local commercial markets. Levitra tablets were labeled to contain $10 \mathrm{mg}$ VARD per tablet (Bayer HealthCare Pharmaceuticals, Germany). Powerecta tablets were labeled to contain $20 \mathrm{mg}$ VARD per tablet (Eva PharmaCompany Giza, Egypt). Verdenodeb tablets were labeled to contain $20 \mathrm{mg}$ VARD per tablet (Debeiky Pharmaceutical, Cairo, Egypt). Cialis ${ }^{\circledR}$ tablets, labeled to contain $20 \mathrm{mg}$ TDF per tablet (Eli Lilly, Australia). Snafi ${ }^{\circledR}$ tablets, labeled to contain $20 \mathrm{mg}$ TDF per tablet (Saudi Pharmaceutical Industries \& Medical Appliances Corporation (SPIMACO), Al-Qassim, Saudi Arabia.

\section{Standard solutions}

A stock standard solution $\left(100 \mu \mathrm{gmL}^{-1}\right)$ of VARD and $\left(200 \mu \mathrm{gmL}^{-1}\right) \mathrm{TDF}$ was prepared by dissolving 10 and $20 \mathrm{mg}$ of pure VARD and TDF, respectivelyin bidistilled water and methanol, respectively further diluted to $100 \mathrm{~mL}$ with the same solvent in a $100 \mathrm{~mL}$ measuring flask. The standard solutions were found stable for at least one week without alteration when kept in an amber colored bottle and stored in a refrigerator when not in use.

\section{Reagents}

$N$-bromosuccinimide (NBS) (0.01 $\left.\mathrm{mol} \mathrm{L}^{-1}\right)$

A stocksolution of $0.01 \mathrm{~mol} \mathrm{~L}^{-1} \mathrm{NBS}$ (Sigma-Aldrish) was freshly prepared by dissolving about $0.178 \mathrm{~g}$ of NBS in least amount of warm bidistilled water in a $100 \mathrm{~mL}$ measuring flask and then diluted to the mark with bidistilled water and standardized ${ }^{51}$. The solution was kept in an amber colored bottle and was diluted appropriately to get $100 \mu \mathrm{g} \mathrm{mL}^{-1} \mathrm{NBS}$ for use in all methods. The NBS solution was stored in a refrigerator when not in use.

Potassium bromide $(1.0 \% \mathrm{w} / \mathrm{v})$

A $1.0 \%$ w/v $\mathrm{KBr}$ solution was also prepared by dissolving $1.0 \mathrm{~g}$ of $\mathrm{KBr}$ in $100 \mathrm{~mL}$ water. 


\section{Hydrochloric acid $\left(5.0 \mathrm{~mol} \mathrm{~L}^{-1}\right)$}

A $5.0 \mathrm{~mol} \mathrm{~L}^{-1}$ of $\mathrm{HCl}$ was prepared by diluting $43 \mathrm{~mL}$ of concentrated acid (Merck, Darmstadt, Germany, Sp. gr. $1.18,37 \%$ ) to $100 \mathrm{~mL}$ with bidistilled water and standardized as recommended previously ${ }^{52}$ prior to use.

Dyes $\left(1000 \mu \mathrm{g} \mathrm{mL} L^{-1}\right)$

A stock solutions of $\left(1000 \mu \mathrm{gL}^{-1}\right)$ amaranth, methylene blue, indigocarmine and orange $\mathrm{G}$ were first prepared by dissolving accurately weighed $112 \mathrm{mg}$ of each dye (Sigma-aldrish, $90 \%$ dye content) in bidistilled water and diluting to volume in a $100 \mathrm{~mL}$ calibrated flask. The solution was then diluted 5.0-fold and 10-fold to get the working concentration of 200 and $100 \mu \mathrm{g} \mathrm{mL}^{-1}$ of (amaranth, indigocarmine or orange $\mathrm{G}$ ) and methylene blue, respectively.

\section{Recommended general procedures}

\section{VARD}

Different aliquots $(0.1-1.6 \mathrm{~mL}),(0.1-1.2 \mathrm{~mL}),(0.1-1.2)$ and $(0.1-1.0 \mathrm{~mL})$ of a standard $100 \mu \mathrm{g} \mathrm{mL}^{-1}$ VARD solution using amaranth, methylene blue and indigocarmine methods, respectively, were transferred into a series of $10 \mathrm{~mL}$ calibrated flasks by means of a micro burette. To each flask $1.0 \mathrm{~mL}$ each of $5.0 \mathrm{~mol} \mathrm{~L}{ }^{-1} \mathrm{HCl} ; 1.5 \mathrm{~mL}$ of NBS solution $\left(100 \mu \mathrm{g} \mathrm{mL}^{-1}\right)$ and $1.0 \mathrm{~mL}$ of $1.0 \%(\mathrm{w} / \mathrm{v}) \mathrm{KBr}$ were added successively. The flasks were stoppered, content mixed and the flasks were kept aside for $5.0 \mathrm{~min}$ with occasional shaking. Finally, 1.5 and $1.2 \mathrm{~mL}$ of $\left(200 \mu \mathrm{gmL}^{-1}\right)$ (amaranth or methylene blue) and indigocarmine solution, respectively were added to each flask and mixed well and then the volume was diluted to the mark with water. The absorbance of each solution was measured at 520, 664 and $610 \mathrm{~nm}$ for amaranth, methylene blue and indigocarmine methods, respectively, after 3.0 min against a reagent blank.

\section{$T D F$}

Different aliquots $(0.2-1.2 \mathrm{~mL}),(0.2-1.5 \mathrm{~mL})$ and $(0.1-1.0 \mathrm{~mL})$ of a standard $100 \mu \mathrm{g} \mathrm{mL}$ TDF solution for amaranth, methylene blue and orange $G$ methods, respectively, were transferred into a series of $10 \mathrm{~mL}$ calibrated flasks by means of a micropipette. To each flask $1.0 \mathrm{~mL}$ each of $5.0 \mathrm{~mol} \mathrm{~L}^{-1} \mathrm{HCl} ; 2.0 \mathrm{~mL}$ of NBS solution $\left(100 \mu \mathrm{gmL}^{-1}\right)$ and $1.0 \mathrm{~mL}$ of $1.0 \%$ $(\mathrm{w} / \mathrm{v}) \mathrm{KBr}$ were added successively. The flasks were stoppered, content mixed and the flasks were kept aside for $5.0 \mathrm{~min}$ with occasional shaking. Finally, 1.2 and $1.5 \mathrm{~mL}$ of $\left(200 \mu \mathrm{gmL}^{-1}\right)$ amaranth or methylene blue and orange $G$ dyes solution, respectively was added to each flask and mixed well and then the volume was diluted to the mark with bidistilled water. The absorbance of each solution was measured at 520, 664 and $478 \mathrm{~nm}$ for amaranth, methylene blue and orange $\mathrm{G}$ methods, respectively, after $3.0 \mathrm{~min}$ against a reagent blank. In all methods, a standard graph was prepared by plotting the absorbance versus the concentration of drug. The concentration of the unknown was read from the calibration graph or computed from the regression equation derived using Beer's law data.

\section{Procedure for pharmaceutical formulations (tablets)}

The contents of twenty tablets of each drug were weighed accurately and ground into a fine powder. An accurate weight of the powdered tablets equivalent to $20 \mathrm{mg}$ VARD was dissolved in bidistilled water or $20 \mathrm{mg}$ TDF was dissolved in methanol with shaking for $5.0 \mathrm{~min}$ and filtered using a Whatman No. 42 filter paper. The filtrate was diluted to the mark with bidistilled water for VARD or methanol for TDF in a $100 \mathrm{~mL}$ measuring flask to give and $200 \mu \mathrm{gmL}^{-1}$ stock solution of VARD or TDF for analysis by spectrophotometric methods. 
A convenient aliquot was then subjected to analysis by the spectrophotometric procedures described above. Determine the nominal content of the tablets using the corresponding regression equation of the appropriate calibration graph.

\section{Results and Discussion}

\section{Absorption spectra}

Many dyes are irreversibly destroyed to colorless species by oxidizing agents in acid medium $^{53}$. The proposed spectrophotometric methods are based on the reaction between VARD or TDF and measured excess of NBS and subsequent determination of the latter by reacting it with a fixed amount of amaranth, methylene blue and indigocarmineor orange $G$ dye and measuring the absorbance at 520, 664 and 610 or $478 \mathrm{~nm}$ (Figure 2). These methods make use of the bleaching action of NBS on the dyes, the decolorization being caused by the oxidative destruction ofthe dyes. VARD or TDF when added in increasing concentrations to a fixed concentration of NBS consumes the latter and there will be a concomitant decrease in the concentration of NBS. When a fixed concentration of either dye is added to decreasing concentrations of NBS, a concomitant increase in the concentration of dye is obtained. Consequently, a proportional increase in the absorbance at the respective $\lambda_{\max }$ is observed with increasing concentrations of VARD or TDF.

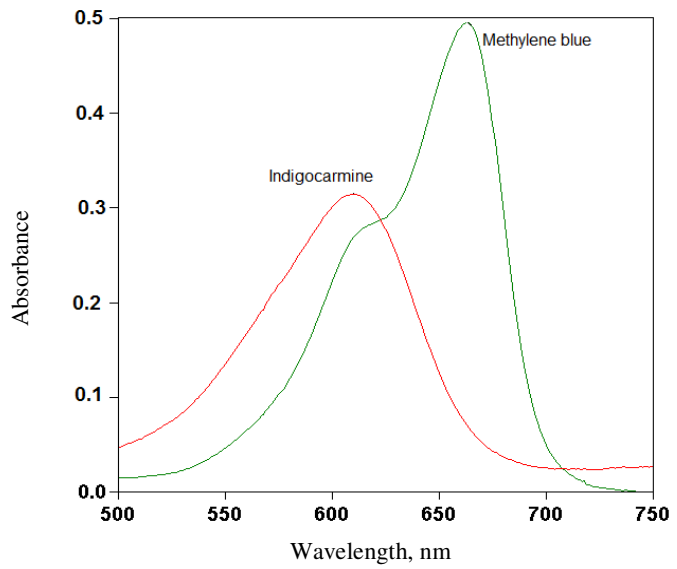

Figure 2. Absorption spectra for the unreacted oxidant that determined by reacting with a fixed amount of dyes and measuring the absorbance at 610 and $664 \mathrm{~nm}$ for indigocarmine and methylene blue methods, respectively in case of VARD

\section{Chemistry of the reactions}

NBS is a strong oxidizing or brominating agent and perhaps the most important positive bromine containing organic compound used for the determination of many pharmaceutical compounds ${ }^{54-58}$. It is also used for the specific purpose of brominating alkenes at the allylic position $^{59}$. The analytical reactions involved two steps; the first one was concerned with the bromination of the investigated drugs with a known excess amount of NBS in hydrochloric acid medium. The second step involved the determination of the excess residual NBS via its reaction with a fixed amount of both amaranth, methylene blue, indigocarmine or orange $\mathrm{G}$ dyes and measuring the absorbance at the respective $\lambda_{\max }$. The tentative reaction scheme of spectrophotometric methods is shown in Scheme 1. In all methods, the absorbance increased linearly with increasing concentration of drugs. The latter methods make use of the bleaching action of NBS on dyes, the discoloration being caused by the oxidative destruction of the dye. 


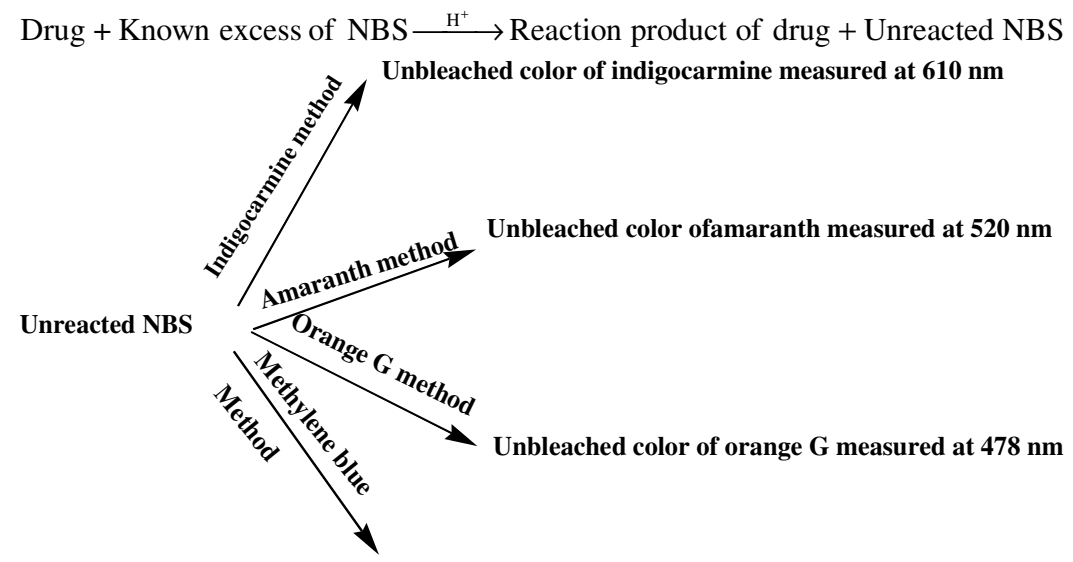

Unbleached color of methylene blue measured at $664 \mathrm{~nm}$

Scheme 1. Tentative reaction scheme for the proposed spectrophotometric methods

\section{Selection of acid type and concentration}

The reaction between VARD and TDF and NBS was performed in different acid media $\mathrm{HCl}$, $\mathrm{H}_{2} \mathrm{SO}_{4}, \mathrm{HNO}_{3}$ and $\mathrm{CH}_{3}-\mathrm{COOH}$ solutions. Better results were suitable in hydrochloric acid medium. The effect of $\mathrm{HCl}$ concentration on the reaction between VARD and TDF and NBS was studied by varying the concentration of $\mathrm{HCl}$ keeping the concentrations of NBS and drug fixed. The reaction was found to be rapid yielding a constant absorbance with maximum sensitivity and stability when the $\mathrm{HCl}$ concentration was $5.0 \mathrm{~mol} \mathrm{~L}^{-1}$ and maintained in the range of $0.25-3.0 \mathrm{~mL}$ of $\mathrm{HCl}\left(5.0 \mathrm{~mol} \mathrm{~L}^{-1}\right)$ in a total volume of $10 \mathrm{~mL}$. The results indicated that, at $1.0-3.0 \mathrm{~mL}$ of $\mathrm{HCl}\left(5.0 \mathrm{~mol} \mathrm{~L}^{-1}\right)$, there were almost same absorbance values were obtained in the presence of VARD and TDF, the absorbance values obtained were constant and were almost the same as those of the reagent blank. At the acid volumes less than $1.0 \mathrm{~mL}$, reaction led to go slower and incomplete. Therefore, $1.0 \mathrm{~mL}$ of $\mathrm{HCl}\left(5.0 \mathrm{~mol} \mathrm{~L}^{-1}\right)$ was used though out the study for both drug.

\section{Effect of NBS concentration}

To investigate the optimum concentration of NBS, different concentrations of NBS were treated in the range of $0.25-3.0 \mathrm{~mL}$ with a fixed concentration dyes in $\mathrm{HCl}$ medium and the absorbance was measured at optimum wavelength. It was found that maximum color intensity of the products was achieved with 1.5 and $2.0 \mathrm{~mL}$ of NBS $\left(100 \mu \mathrm{gmL}^{-1}\right)$ forVARD and TDF, respectively (Figure 3).

\section{Effect of $\mathrm{KBr}$ concentration}

The effect of $\mathrm{KBr}$ concentration was studied in the range of $0.5-2.5 \mathrm{~mL} .1 .0 \mathrm{~mL}$ of $1.0 \%$ $(\mathrm{w} / \mathrm{v}) \mathrm{KBr}$ was chosen as an optimum volume to accelerate the oxidation process.

\section{Effect of dye concentration}

The effect of amaranth, methylene blue, indigocarmine or orange G concentration on the intensity of the color developed was carried out to obtain the optimum concentration of dyes that produces the maximum and reproducible color intensity by reducing the residual of NBS. The effect dye concentration was studied in the range of $0.25-3.0 \mathrm{~mL}$ of each dye $\left(200 \mu \mathrm{g} \mathrm{mL}^{-1}\right)$. It was found that maximum color intensity of the oxidation products was achieved with 
1.5 and $1.2 \mathrm{~mL}$ of (amaranth or methylene blue) and indigocarmine solution, respectively in case of VARD (Figure 4), but with 1.2 and $1.5 \mathrm{~mL}$ of (amaranth or methylene blue) and orange $\mathrm{G}$ dyes solution, respectively for TDF.

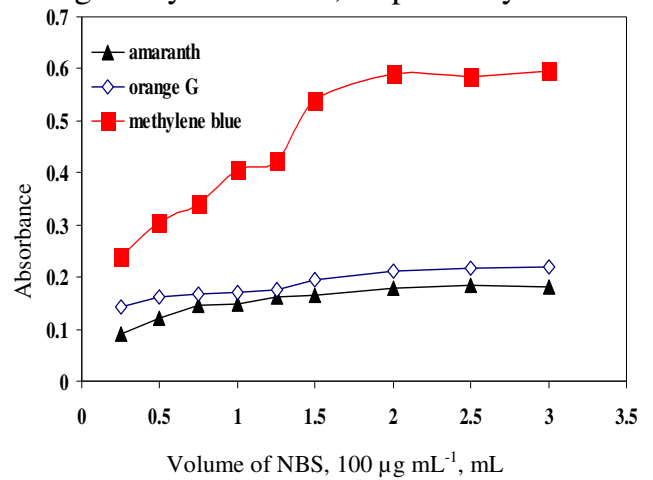

Figure 3. Effect of volume of NBS $\left(100 \mu \mathrm{gmL}^{-1}\right)$ of the oxidation product of TDF with NBS and dyes in $\mathrm{HCl}$ medium

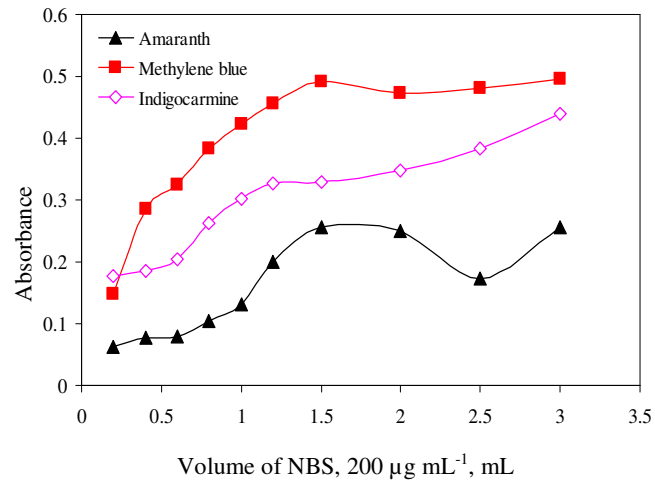

Figure 4. Effect of volume of dyes $\left(200 \mu \mathrm{gmL}^{-1}\right)$ of the oxidation product of VARD with NBS and dyes in $\mathrm{HCl}$ medium

\section{Effect of temperature and mixing time}

The effect of temperature was studied by heating a series of sample and blank solutions at different temperatures ranging from 25 to $60{ }^{\circ} \mathrm{C}$ in water bath. It was found that raising the temperature does not accelerate the oxidation process and does not give reproducible results, so maximum color intensity was obtained at room temperature $\left(25 \pm 2{ }^{\circ} \mathrm{C}\right)$. The effect of mixing time required completing oxidation of the studied drugs and for reducing the excess oxidant was studied by measuring the absorbance of sample solution against blank solution prepared similarly at various time intervals $2.0-20 \mathrm{~min}$. It was found that the contact times gave constant and reproducible absorbance values at $5.0 \mathrm{~min}$ at room temperature $\left(25 \pm 2{ }^{\circ} \mathrm{C}\right)$ for each drug. The time required for complete oxidation of the drug is not critical and any delay up to $15 \mathrm{~min}$ in the determination of unreacted NBS had no effect on the absorbance. A 3.0 min standing time was found necessary for the complete bleaching of the dye color by the residual NBS for each drug was found necessary for complete reduction of residual NBS by all dyesand the absorbance of the unreacted dye was stable for at least $6.0 \mathrm{~h}$, thereafter

\section{Effect of sequence of addition}

The optimum sequence of addition was drug-HCl-NBS-KBr and then dye.Other sequences gave lower absorbance values under the same experimental conditions.

\section{Method validation}

The proposed methods have been validated for linearity, sensitivity, precision, accuracy, selectivity and recovery.

\section{Linearity and sensitivity}

Under the optimum conditions a linear correlation was found between absorbance $\lambda_{\max }$ and the concentration of VARD and TDF in the ranges of $1.0-16 \mu \mathrm{gmL}^{-1}$ and $1.0-15$, respectively. The calibration graph is described by the equation:

$$
\mathrm{A}=\mathrm{a}+\mathrm{b} \mathrm{C}
$$

Where $\mathrm{A}=$ absorbance, $\mathrm{a}=$ intercept, $\mathrm{b}=$ slope and $\mathrm{C}=$ concentration in $\mu \mathrm{gmL}^{-1}$, obtained by the method of least squares. Correlation coefficient, intercept and slope of the calibration 
data are summarized in Table 2. For accurate determination, Ringbom concentration range $e^{60}$ was calculated by plotting log concentration of drug in $\mu \mathrm{gmL}^{-1}$ against transmittance $\%$ from which the linear portion of the curve gives an accurate range of microdetermination of VARD and TDF and represented in Table 2. Sensitivity parameters such as apparent molar absorptivity and Sandell's sensitivity values, as well as the limits of detection and quantification, were calculated as per the current ICH guidelines ${ }^{61}$ and illustrated in Table 2 . The high molar absorptivity and lower Sandell sensitivity values reflect the good and high sensitivity of the proposed methods. The validity of the proposed methods was evaluated by statistical analysis ${ }^{62}$ between the results achieved from the proposed methods and that of the reported method. Regarding the calculated Student's $t$-test and variance ratio $F$-test (Table 2), there is no significant difference between the proposed and reported method ${ }^{40,47}$ regarding accuracy and precision. The limits of detection (LOD) and quantification (LOQ) were calculated according to the same guidelines using the formulas ${ }^{61,62}$ :

$$
\mathrm{LOD}=3.3 \sigma / \mathrm{s} \text { and } \mathrm{LOQ}=10 \sigma / \mathrm{s}
$$

Where $\sigma$ is the standard deviation of five reagent blank determinations, and $\mathrm{s}$ is the slope of the calibration curve.

\section{Accuracy and precision}

In order to evaluate the precision of the proposed methods, solutions containing three different concentrations of VARD and TDF were prepared and analyzed in six replicates. The analytical results obtained from this investigation are summarized in Table 3 . Lower values of the relative standard deviation (\% R.S.D) and percentage relative error (\% R.E) indicate the precision and accuracy of the proposed methods. The percentage relative error is calculated using the following equation:

$$
\% \text { R.E. }=\left[\frac{\text { found }- \text { taken }}{\text { taken }}\right] \times 100
$$

The assay procedure was repeated six times, and percentage relative standard deviation (\% R.S.D) values were obtained within the same day to evaluate repeatability (intra-day precision) and over five different days to evaluate intermediate precision (inter-day precision).

For the same concentrations of drugs inter- and intra-day accuracy of the methods was also evaluated. The percentage recovery values with respect to found concentrations of each drug were evaluated to ascertain the accuracy of the methods. The recovery values close to $100 \%$ as compiled in Table 3 shows that the proposed methods are very accurate.

\section{Robustness and ruggedness}

For the evaluation of method robustness, volume of HClwas slightly altered $(1.0 \pm 0.2 \mathrm{~mL})$ and the reaction time (after adding NBS, time varied was 5.0 $\pm 2.0 \mathrm{~min}$ ) were slightly varied deliberately in the three methods for each drug. The analysis was performed with altered conditions by taking three different concentrations of drugs and the methods were found to remain unaffected as shown by the RSD values in the ranges of $0.9-2.30 \%$ and $0.78-2.5 \%$ for VARD and TDF, respectively. Methods ruggedness was expressed as the RSD of the same procedure applied by three different analysts as well as using three different instruments (spectrophotometers). The inter-analysts RSD were in the ranges $0.84-2.50 \%$ and $0.85-2.10 \%$ for VARD and TDF, respectively, whereas the inter-instruments RSD ranged from $0.75-2.45 \%$ and $0.90-2.40 \%$ for VARD and TDF, respectively suggesting that the developed methods were rugged. The results are shown in Table 4. 
Table 2. Analytical and regression parameters of proposed oxidation spectrophotometric methods for determination of VARD and TDF

\begin{tabular}{|c|c|c|c|c|c|c|}
\hline \multirow[b]{2}{*}{ Parameters } & \multicolumn{3}{|c|}{ VARD } & \multicolumn{3}{|c|}{ TDF } \\
\hline & Amaranth & $\begin{array}{l}\text { Methylene } \\
\text { blue }\end{array}$ & Indigocarmine & Amaranth & $\begin{array}{l}\text { Methylene } \\
\text { blue }\end{array}$ & $\begin{array}{l}\text { Orange } \\
\mathrm{G}\end{array}$ \\
\hline $\begin{array}{l}\text { Beer's law } \\
\text { limits, } \mu \mathrm{g} \mathrm{mL}{ }^{-1}\end{array}$ & $1.0-16$ & $1.0-12$ & $1.0-10$ & $2.0-12$ & $2.0-15$ & $1.0-10$ \\
\hline $\begin{array}{l}\text { Ringboom } \\
\text { limits, } \mu \mathrm{g} \mathrm{mL}{ }^{-1}\end{array}$ & $3.0-13$ & $3.0-10$ & $2.0-8.0$ & $4.0-10$ & $4.0-12$ & $2.0-8.0$ \\
\hline $\begin{array}{l}\text { Molar absorptivity, } \\
\times 10^{4} \mathrm{~L} \mathrm{~mol}^{-1} \mathrm{~cm}^{-1}\end{array}$ & 0.9717 & 2.5114 & 2.208 & 0.9595 & 1.8077 & 0.7970 \\
\hline 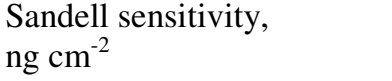 & 57.79 & 22.36 & 25.43 & 40.58 & 21.54 & 48.86 \\
\hline Regression equation $^{\mathrm{a}}$ & & & & & & \\
\hline Intercept (a) & 0.0041 & 0.0059 & 0.0027 & -0.0009 & 0.004 & 0.0035 \\
\hline $\begin{array}{l}\text { Standard deviation of } \\
\text { intercept }\left(\mathrm{S}_{\mathrm{a}}\right)\end{array}$ & 0.007 & 0.006 & 0.005 & 0.006 & 0.005 & 0.0048 \\
\hline Slope (b) & 0.0156 & 0.042 & 0.038 & 0.0206 & 0.0454 & 0.0229 \\
\hline $\begin{array}{l}\text { Standard deviation of } \\
\text { slope }\left(S_{b}\right)\end{array}$ & 0.011 & 0.008 & 0.009 & 0.008 & 0.007 & 0.0093 \\
\hline Correlation coefficient, $(r)$ & 0.9993 & 0.9997 & 0.9996 & 0.9997 & 0.9996 & 0.999 \\
\hline Mean \pm SD & $100.21 \pm 1.22$ & $99.90 \pm 0.76$ & $100.10 \pm 1.14$ & $100.01 \pm 1.33$ & $100.36 \pm 1.40$ & $100.34 \pm 1.34$ \\
\hline RSD\% & 1.22 & 0.76 & 1.14 & 1.33 & 1.40 & 1.34 \\
\hline RE\% & 1.28 & 0.80 & 1.20 & 1.40 & 1.47 & 1.41 \\
\hline Limit of detection, $\mu \mathrm{g} \mathrm{mL}^{-1}$ & 0.29 & 0.27 & 0.26 & 0.58 & 0.55 & 0.27 \\
\hline $\begin{array}{l}\text { Limit of quantification, } \\
\mu \mathrm{g} \mathrm{mL}^{-1}\end{array}$ & 0.97 & 0.90 & 0.87 & 1.93 & 1.83 & 0.90 \\
\hline $\begin{array}{l}\text { Calculated } \\
t \text {-value }\end{array}$ & 0.08 & 0.85 & 0.28 & 0.52 & 0.90 & 0.91 \\
\hline $\begin{array}{l}\text { Calculated } \\
F \text {-value }^{\text {b }}\end{array}$ & 4.75 & 1.84 & 4.14 & 1.06 & 1.18 & 1.08 \\
\hline
\end{tabular}

5.05 , respectively at confidence limit at $95 \%$ confidence level and five degrees of freedom $(p=0.05)$ 
Table 3. Results of intra-day and inter-day accuracy and precision study for VARD obtained by the proposed methods

\begin{tabular}{cccccc}
\hline Method & $\begin{array}{c}\text { Taken, } \\
\mu \mathrm{g} \mathrm{mL}\end{array}$ & $\begin{array}{c}\text { Recovery } \\
\%\end{array}$ & $\begin{array}{c}\text { Precision } \\
\text { RSD \% }\end{array}$ & $\begin{array}{c}\text { Accuracy } \\
\text { RE \% }\end{array}$ & $\begin{array}{c}\text { Confidence } \\
\text { Limit }^{\mathrm{b}}\end{array}$ \\
\hline Amaranth & & \multicolumn{4}{c}{ Intra-day } \\
& 4.0 & 99.20 & 0.83 & -0.80 & $3.968 \pm 0.035$ \\
Methylene blue & 12.0 & 100.30 & 1.14 & 0.30 & $8.024 \pm 0.096$ \\
& 3.0 & 99.60 & 1.55 & -0.40 & $11.952 \pm 0.194$ \\
Indigocarmine & 6.0 & 99.00 & 0.76 & -1.0 & $2.97 \pm 0.024$ \\
& 9.0 & 99.80 & 1.28 & -0.60 & $5.964 \pm 0.08$ \\
& 2.0 & 99.60 & 1.93 & -0.20 & $8.982 \pm 0.182$ \\
Amaranth & 4.0 & 99.30 & 1.42 & -0.40 & $1.992 \pm 0.022$ \\
& 8.0 & 100.70 & 1.65 & -0.70 & $3.972 \pm 0.059$ \\
& 4.0 & 99.40 & 0.51 & -0.60 & $3.056 \pm 0.14$ \\
Methylene blue & 8.0 & 99.60 & 0.97 & -0.40 & $7.968 \pm 0.081$ \\
& 12 & 99.10 & 1.58 & -0.90 & $11.892 \pm 0.197$ \\
& 3.0 & 99.20 & 0.82 & -0.80 & $2.976 \pm 0.026$ \\
Indigocarmine & 6.0 & 100.40 & 1.16 & 0.40 & $6.024 \pm 0.073$ \\
& 9.0 & 100.10 & 1.40 & 0.10 & $9.009 \pm 0.132$ \\
& 2.0 & 99.30 & 0.95 & -0.70 & $1.986 \pm 0.02$ \\
& 4.0 & 100.60 & 1.38 & 0.60 & $4.024 \pm 0.058$ \\
& 8.0 & 99.40 & 1.85 & -0.60 & $7.952 \pm 0.154$ \\
\hline
\end{tabular}

${ }^{a} R S D \%$, percentage relative standard deviation; $R E \%$, percentage relative error. ${ }^{b}$ Mean \pm standard error

Table 4. Results of intra-day and inter-day accuracy and precision study for TDF obtained by the proposed methods

\begin{tabular}{|c|c|c|c|c|c|}
\hline Method & $\begin{array}{l}\text { Taken, } \\
\mu \mathrm{g} \mathrm{mL}^{-1}\end{array}$ & $\begin{array}{c}\text { Recovery } \\
\%\end{array}$ & $\begin{array}{l}\text { Precision } \\
\text { RSD \% }\end{array}$ & $\begin{array}{c}\text { Accuracy } \\
\text { RE \% }\end{array}$ & $\begin{array}{c}\text { Confidence } \\
\text { Limit }^{b}\end{array}$ \\
\hline & \multicolumn{5}{|c|}{ Intra-day } \\
\hline \multirow{3}{*}{ Amaranth } & 3.0 & 99.50 & 0.76 & -0.50 & $2.985 \pm 0.024$ \\
\hline & 6.0 & 99.10 & 1.05 & -0.90 & $5.946 \pm 0.062$ \\
\hline & 9.0 & 99.90 & 1.60 & -0.10 & $8.991 \pm 0.151$ \\
\hline \multirow[t]{3}{*}{ Methylene blue } & 4.0 & 99.00 & 0.87 & -1.00 & $3.96 \pm 0.036$ \\
\hline & 8.0 & 99.70 & 1.06 & -0.30 & $7.976 \pm 0.089$ \\
\hline & 12 & 100.30 & 1.79 & 0.30 & $12.036 \pm 0.226$ \\
\hline \multirow[t]{3}{*}{ Orange $\mathrm{G}$} & 2.0 & 99.30 & 1.12 & -0.70 & $1.986 \pm 0.023$ \\
\hline & 4.0 & 100.80 & 1.30 & 0.80 & $4.032 \pm 0.055$ \\
\hline & 8.0 & 100.70 & $\begin{array}{l}1.85 \\
\text { Inter-day }\end{array}$ & 0.70 & $8.056 \pm 0.156$ \\
\hline \multirow[t]{3}{*}{ Amaranth } & 3.0 & 99.40 & 0.83 & -0.60 & $2.982 \pm 0.026$ \\
\hline & 6.0 & 99.20 & 1.27 & -0.80 & $5.952 \pm 0.079$ \\
\hline & 9.0 & 99.60 & 1.69 & -0.40 & $7.968 \pm 0.141$ \\
\hline \multirow[t]{3}{*}{ Methylene blue } & 4.0 & 99.20 & 0.77 & -0.80 & $3.968 \pm 0.031$ \\
\hline & 8.0 & 100.20 & 0.98 & 0.20 & $8.016 \pm 0.082$ \\
\hline & 12 & 100.50 & 1.76 & 0.50 & $12.06 \pm 0.223$ \\
\hline \multirow[t]{3}{*}{ Orange $\mathrm{G}$} & 2.0 & 99.80 & 1.04 & -0.20 & $1.996 \pm 0.022$ \\
\hline & 4.0 & 99.40 & 1.45 & -0.40 & $3.976 \pm 0.061$ \\
\hline & 8.0 & 99.70 & 1.90 & -0.30 & $7.976 \pm 0.159$ \\
\hline
\end{tabular}

${ }^{a} R S D \%$, percentage relative standard deviation; $R E \%$, percentage relative error. ${ }^{b}$ Mean \pm standard error 
Table 5. Results of method robustness and ruggedness (all values in RSD\%) studies for VARD and TDF

\begin{tabular}{|c|c|c|c|c|c|}
\hline \multirow{4}{*}{ Methods } & \multirow{4}{*}{ 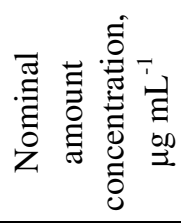 } & \multicolumn{4}{|c|}{ RSD\% } \\
\hline & & \multicolumn{2}{|c|}{ Robustness } & \multicolumn{2}{|c|}{ Ruggedness } \\
\hline & & \multicolumn{4}{|c|}{ Variable alerted $^{\mathrm{a}}$} \\
\hline & & $\begin{array}{l}\text { Acid volume } \\
(\mathrm{n}=3)\end{array}$ & $\begin{array}{l}\text { Reaction } \\
\text { time }(n=3)\end{array}$ & $\begin{array}{c}\text { Different } \\
\text { analysts }(n=3)\end{array}$ & $\begin{array}{c}\text { Different } \\
\text { instruments }(n=3)\end{array}$ \\
\hline & \multicolumn{5}{|c|}{ VARD } \\
\hline \multirow[t]{3}{*}{ Amaranth } & 4.0 & 1.34 & 0.90 & 0.84 & 0.75 \\
\hline & 8.0 & 1.85 & 1.12 & 1.40 & 1.50 \\
\hline & 12 & 2.20 & 1.90 & 2.10 & 2.40 \\
\hline \multirow[t]{3}{*}{ Methylene blue } & 3.0 & 1.15 & 0.92 & 1.25 & 0.85 \\
\hline & 6.0 & 1.60 & 1.80 & 1.94 & 1.70 \\
\hline & 9.0 & 2.30 & 2.15 & 2.50 & 2.10 \\
\hline \multirow[t]{4}{*}{ Indigocarmine } & 2.0 & 1.14 & 1.06 & 0.90 & 0.80 \\
\hline & 4.0 & 1.70 & 1.95 & 1.70 & 1.80 \\
\hline & 8.0 & 2.20 & 2.30 & 2.25 & 2.45 \\
\hline & \multicolumn{5}{|c|}{ TDF } \\
\hline \multirow[t]{3}{*}{ Amaranth } & 3.0 & 0.82 & 0.95 & 1.05 & 1.15 \\
\hline & 6.0 & 1.46 & 1.29 & 1.40 & 1.55 \\
\hline & 9.0 & 1.93 & 2.05 & 2.10 & 1.93 \\
\hline \multirow[t]{3}{*}{ Methylene blue } & 4.0 & 1.02 & 0.78 & 1.10 & 0.90 \\
\hline & 8.0 & 1.50 & 1.42 & 1.30 & 1.50 \\
\hline & 12 & 2.20 & 1.90 & 2.10 & 2.40 \\
\hline \multirow[t]{3}{*}{ Orange $\mathrm{G}$} & 2.0 & 1.10 & 0.90 & 0.85 & 0.94 \\
\hline & 4.0 & 2.10 & 1.85 & 1.70 & 1.90 \\
\hline & 8.0 & 2.50 & 2.30 & 1.85 & 2.05 \\
\hline
\end{tabular}

${ }^{a}$ Volume of $\left(5.0 \mathrm{~mol} \mathrm{~L} \mathrm{~L}^{-1}\right) \mathrm{HCl}$ is $(1.0 \pm 0.2 \mathrm{~mL})$ and reaction time is $(5.0 \pm 2.0 \mathrm{~min})$ (after adding $\mathrm{NBS}$ ) were used

\section{Recovery studies}

To ascertain the accuracy, reliability and validity of the proposed methods, recovery experiment was performed through standard addition technique. This study was performed by spiking three different levels of pure drugs $(50,100$ and $150 \%$ of the level present in the tablet) to a fixed amount of drugs in tablet powder (pre-analysed) andthe total concentration was found by the proposed methods. The determination with each level was repeated three times and the percent recovery of the added standard was calculated from:

$$
\% \text { Recovery }=\frac{\left[C_{F}-C_{T}\right]}{C_{p}} x 100
$$

Where $C_{F}$ is the total concentration of the analyte found, $C_{T}$ is a concentration of the analyte present in the tablet preparation; $C_{P}$ is a concentration of analyte (pure drugs) added to tablets preparations. The results of this study presented in Table 6 revealed that the accuracy of the proposed methods was unaffected by the various excipients present in tablets which did not interfere in the assay. 
Table 6. Results of recovery experiments by standard addition method for the determination of VARD and TDF in tablets using the proposed methods

\begin{tabular}{|c|c|c|c|c|c|c|c|c|}
\hline \multirow[b]{2}{*}{ Samples } & \multirow{2}{*}{$\begin{array}{c}\text { Taken } \\
\text { drug in } \\
\text { tablet, } \\
\mu \mathrm{g} \mathrm{mL}^{-1}\end{array}$} & \multirow[b]{2}{*}{$\begin{array}{l}\text { Pure drug } \\
\text { Added, } \\
\mu \mathrm{g} \mathrm{mL}^{-1}\end{array}$} & \multicolumn{2}{|c|}{ Amaranth } & \multicolumn{2}{|c|}{ Methylene blue } & \multicolumn{2}{|c|}{ Indigocarmine } \\
\hline & & & $\begin{array}{c}\text { Total } \\
\text { Found, } \\
\mu \mathrm{g} \mathrm{mL}^{-1}\end{array}$ & $\begin{array}{l}\text { Recovery }^{\mathrm{a}} \\
(\%) \pm \mathrm{SD}\end{array}$ & $\begin{array}{c}\text { Total } \\
\text { found, } \\
\mu \mathrm{g} \mathrm{mL} \mathrm{mL}^{-1}\end{array}$ & $\begin{array}{c}\text { Recovery }^{\mathrm{a}} \\
(\%) \pm \mathrm{SD}\end{array}$ & $\begin{array}{c}\text { Total } \\
\text { Found, } \\
\mu \mathrm{g} \mathrm{mL}^{-1}\end{array}$ & $\begin{array}{c}\text { Recovery }^{\mathrm{a}} \\
(\%) \pm \mathrm{SD}\end{array}$ \\
\hline Levitra & 4.0 & 2.0 & 5.958 & $99.30 \pm 0.80$ & 6.036 & $100.60 \pm 0.55$ & 5.934 & $98.90 \pm 0.79$ \\
\hline tablets & 4.0 & 4.0 & 8.056 & $100.70 \pm 1.09$ & 4.88 & $100.50 \pm 1.10$ & 7.936 & $99.20 \pm 1.26$ \\
\hline$(10 \mathrm{mg})$ & 4.0 & 6.0 & 10.12 & $101.20 \pm 1.37$ & 9.91 & $99.10 \pm 1.50$ & 10.04 & $100.40 \pm 1.60$ \\
\hline Powerecta & 4.0 & 2.0 & 6.03 & $100.50 \pm 0.63$ & 6.072 & $101.20 \pm 0.94$ & 5.97 & $99.50 \pm 1.15$ \\
\hline tablets & 4.0 & 4.0 & 8.144 & $101.80 \pm 0.96$ & 8.056 & $100.70 \pm 1.29$ & 8.032 & $100.40 \pm 0.90$ \\
\hline$(20 \mathrm{mg})$ & 4.0 & 6.0 & 10.09 & $100.90 \pm 1.17$ & 9.90 & $99.00 \pm 1.72$ & 9.92 & $99.20 \pm 0.82$ \\
\hline Verdenode & 4.0 & 2.0 & 5.958 & $99.30 \pm 0.72$ & 6.036 & $100.60 \pm 0.65$ & 5.976 & $99.60 \pm 0.79$ \\
\hline b & 4.0 & 4.0 & 8.032 & $100.40 \pm 1.48$ & 7.88 & $98.50 \pm 1.36$ & 7.944 & $99.30 \pm 0.56$ \\
\hline \multirow[t]{3}{*}{$\begin{array}{l}\text { tablets } \\
(20 \mathrm{mg})\end{array}$} & 4.0 & 6.0 & 9.87 & $98.70 \pm 1.80$ & 9.94 & $99.40 \pm 1.55$ & 10.06 & $100.60 \pm 1.20$ \\
\hline & \multirow{2}{*}{$\begin{array}{c}\text { Taken } \\
\text { drug in } \\
\text { tablet } \\
\mu \mathrm{g} \mathrm{mL}^{-1}\end{array}$} & \multirow[b]{2}{*}{$\begin{array}{l}\text { Pure drug } \\
\text { Added } \\
\mu \mathrm{g} \mathrm{mL} L^{-1}\end{array}$} & \multicolumn{2}{|c|}{ Amaranth } & \multicolumn{2}{|c|}{ Methylene blue } & \multicolumn{2}{|c|}{ Orange $\mathrm{G}$} \\
\hline & & & $\begin{array}{c}\text { Total } \\
\text { found } \\
\mu \mathrm{g} \mathrm{mL}^{-1}\end{array}$ & $\begin{array}{l}\text { Recovery }^{\mathrm{a}} \\
(\%) \pm \mathrm{SD}\end{array}$ & $\begin{array}{c}\text { Total } \\
\text { found } \\
\mu \mathrm{g} \mathrm{mL} \mathrm{m}^{-1}\end{array}$ & $\begin{array}{c}\text { Recovery }{ }^{a} \\
(\%) \pm \mathrm{SD}\end{array}$ & $\begin{array}{c}\text { Total } \\
\text { found } \\
\mu \mathrm{g} \mathrm{mL}^{-1}\end{array}$ & $\begin{array}{l}\text { Recovery }^{\mathrm{a}} \\
(\%) \pm \mathrm{SD}\end{array}$ \\
\hline Cialis $^{\left({ }^{B}\right.}$ & 4.0 & 2.0 & 5.916 & $98.60 \pm 1.24$ & 6.90 & $101.50 \pm 0.75$ & 6.072 & $101.20 \pm 0.95$ \\
\hline tablets & 4.0 & 4.0 & 8.096 & $101.20 \pm 1.56$ & 7.952 & $99.40 \pm 1.65$ & 7.896 & $98.70 \pm 0.80$ \\
\hline$(20 \mathrm{mg})$ & 4.0 & 6.0 & 9.90 & $99.00 \pm 0.87$ & 10.08 & $100.80 \pm 1.35$ & 10.20 & $102.00 \pm 1.20$ \\
\hline Snafi ${ }^{\circledR}$ & 4.0 & 2.0 & 6.024 & $100.40 \pm 0.69$ & 5.91 & $98.50 \pm 0.84$ & 5.964 & $99.40 \pm 0.68$ \\
\hline tablets & 4.0 & 4.0 & 7.856 & $98.20 \pm 1.35$ & 8.208 & $102.60 \pm 1.30$ & 8.072 & $100.90 \pm 1.50$ \\
\hline$(20 \mathrm{mg})$ & 4.0 & 6.0 & 10.32 & $103.20 \pm 1.15$ & 9.85 & $98.50 \pm 1.57$ & 10.15 & $101.50 \pm 1.80$ \\
\hline
\end{tabular}

\section{Application of pharmaceutical formulations (tablets)}

The proposed methods were applied to the determination of VARD and TDF in pharmaceutical formulations (tablets). The results in Table 7 showed that the methods are successful for the determination of VARD and TDF and that the excipients in the dosage forms do not interfere. A statistical comparison of theresults obtained from the assay of VARD and TDF by the proposed methods and the reported methods ${ }^{40,47}$ for the same batch of material is presented in Table 7. The results agree well with the label claim and also were in agreement with the results obtained by the reported methods ${ }^{40,47}$. When the results were statistically compared with those of the reported methods by applying the Student's $t$-test for accuracy and $F$-test for precision, the calculated $t$-value and $F$-value at $95 \%$ confidence level did not exceed the tabulated values for five degrees of freedom ${ }^{62}$. Hence, no significant difference between the proposed methods and the reported methods at the $95 \%$ confidence level with respect to accuracy and precision.

Table 7. Results of analysis of tablets by the proposed methodsfor the determination of VARD and TDF and statistical comparison with the reference methods

\begin{tabular}{|c|c|c|c|c|}
\hline \multirow{3}{*}{ Samples } & \multicolumn{4}{|c|}{ Recovery $^{\mathrm{a}}(\%) \pm \mathrm{SD}$} \\
\hline & \multicolumn{3}{|c|}{ Proposed Methods } & \multirow{2}{*}{$\begin{array}{c}\text { Reported } \\
\text { methods [Ref] }\end{array}$} \\
\hline & Amaranth & Methylene blue & Indigocarmine & \\
\hline $\begin{array}{l}\text { Levitra tablets } \\
\text { (10 mg VARD) }\end{array}$ & $99.45 \pm 0.80$ & $100.36 \pm 0.47$ & $99.28 \pm 0.71$ & $99.92 \pm 0.64[40]$ \\
\hline$t$-value $b$ & 1.02 & 1.23 & 1.49 & \\
\hline$F$-value $e^{b}$ & 1.56 & 1.85 & 1.23 & \\
\hline $\begin{array}{l}\text { Powerectatablets } \\
\text { (20 mg VARD) }\end{array}$ & $100.21 \pm 0.50$ & $99.64 \pm 0.38$ & $99.40 \pm 0.85$ & $99.90 \pm 0.67[40]$ \\
\hline
\end{tabular}




\begin{tabular}{|c|c|c|c|c|}
\hline$t$-value ${ }^{b}$ & 0.82 & 0.75 & 1.03 & \\
\hline$F$-value $e^{b}$ & 1.79 & 3.1 & 1.6 & \\
\hline $\begin{array}{l}\text { Verdenodebtablets } \\
\text { (20 mg VARD) }\end{array}$ & $99.26 \pm 0.90$ & $99.76 \pm 0.54$ & $99.30 \pm 0.79$ & $99.50 \pm 0.72[40]$ \\
\hline$t$-value $b$ & 0.46 & 0.64 & 0.41 & \\
\hline$F$-value ${ }^{b}$ & 1.56 & 1.77 & 1.2 & \\
\hline & Amaranth & Methylene blue & Orange $\mathrm{G}$ & \\
\hline $\begin{array}{l}\text { Cialis }^{\circledR} \text { tablets } \\
(20 \mathrm{mg} \text { TDF })\end{array}$ & $100.32 \pm 0.32$ & $99.50 \pm 0.73$ & $99.20 \pm 0.66$ & $99.79 \pm 0.56[47]$ \\
\hline$t$-value $b$ & 1.83 & 0.7 & 1.52 & \\
\hline$F$-value $e^{b}$ & 3.06 & 1.69 & 1.38 & \\
\hline $\begin{array}{l}\text { Snafi }{ }^{\circledR} \text { tablets } \\
(20 \mathrm{mg} \text { TDF })\end{array}$ & $99.48 \pm 0.50$ & $99.90 \pm 0.69$ & $99.82 \pm 0.39$ & $99.60 \pm 0.51[47]$ \\
\hline$t$-value ${ }^{b}$ & 0.37 & 0.78 & 0.77 & \\
\hline$F$-value $e^{b}$ & 1.04 & 1.83 & 1.71 & \\
\hline
\end{tabular}

\section{Conclusion}

Three new, useful simple, rapid and cost-effective spectrophotometric methods have been developed for determination of VARD and TDF in bulk drugs and in its tablets using NBS as brominating agent and validated as per the current ICH guidelines. The present spectrophotometric methods are characterized by simplicity of operation, high selectivity, comparable sensitivity, low-cost instrument; they do not involve any critical experimental variable and are free from tedious and time-consuming extraction steps and use of organic solvents unlike many of the previous methods reported for VARD and TDF. The assay methods have some additional advantages involve less stringent control of experimental parameters such as the stability of the colored system, accuracy, reproducibility, time of analysis, temperature independence and cheaper chemicals. These advantages encourage the application of the proposed methods in routine quality control analysis of VARD and TDF in pure and dosage forms.

\section{Conflict of interest}

The authors declare that they have no conflict of interests with the company name used in the paper.

\section{References}

1. Abdel-Aziz A A M, Asiri Y A, El-Azab A S, Al-Omar M A and Kunieda T, Anal Profiles Drug Subst Excipients, 2011, 36, 287-329; DOI:10.1016/B978-0-12-3876676.00008-7

2. Ashour A E, Rahman A F M M and Kassem M G, Anal Profiles Drug Subst Excipients ,2014, 39, 515-544; DOI:10.1016/B978-0-12-800173-8.00009-X

3. Aboul-Enein H Y, Ghanem A, Hoenen H and Michael K, J Liq Chromatogr Relat Technol., 2005, 28(9), 1357-1365; DOI:10.1081/JLC-200054835

4. Zou P, Oh S S Y, Hou P, Low M Y and Koh H L, J Chromatogr A, 2006, 1104(1-2), 113-122; DOI:10.1016/j.chroma.2005.11.103

5. Zhu X, Xiao S, Chen B, Zhang F, Yao S, Wan Z, Yang D and Han H, J Chromatogr A, 2005, 1066(1-2), 89-95; DOI:10.1016/j.chroma.2005.01.038

6. Zhang Z, Kang S, Xu M, Ma M, Chen B and Yao S, Se Pu., 2005, 23(4), 358-361. 
7. SubbaRao D V, Surendranath K V, Radhakrishnanand P, Suryanarayana M V and Raghuram P, Chromatographia, 2008, 68(9), 829-835; DOI:10.1365/s10337-0080766-4

8. Bartošová Z, Jirovský D and Horna A, J Chromatogr A, 2011, 1218(44), 7996-8001; DOI:10.1016/j.chroma.2011.09.001

9. Lake S T, Altman P M, Vaisman J and Addison R S, Biomed Chromatogr., 2010, 24(8), 846-851; DOI:10.1002/bmc.1375

10. Manisha G, Usha P and Vandana P, Am J Pharm Tech Res., 2013, 3, 928.

11. Di Y, Zhao M, Nie Y, Wang F and Lv J, J Autom Methods Manag Chem., 2011, 1-6.

12. Kumar K K, Rao C K, Reddy Y R K and Mukkanti K A, Am J Anal Chem., 2012, 3, 59; DOI: 10.4236/ajac.2012.31009

13. Papoutsis I, Nikolaou P, Athanaselis S, Pistos C, Maravelias C and Spiliopoulou C, $J$ Mass Spectrom., 2011, 46(1), 71-76; DOI:10.1002/jms.1868

14. Strano-Rossi S, Anzillotti L, de la Torre X and Botrè F, Rapid Commun Mass Spectrrom., 2010, 24(11), 1697-1706; DOI:10.1002/rcm.4568

15. Idris A M and Alnajjar A O, Acta Chromatogr., 2007, 19, 97-109.

16. Flores J R, Nevado J J B, Penalvo G C and Diez N M, J Chromatogr B, 2004, 811, 231-236; DOI:10.1016/j.jchromb.2004.07.016

17. Uslu B B, Dogan, S A, Ozkan and Aboul-Enein H Y, Anal Chim Acta, 2005, 552(12), 127-134; DOI:10.1016/j.aca.2005.07.040

18. Ghoneim M M, Hassanein A M, Salahuddin N A, El-Desoky H S and El fiky M N, $J$ Solid State Electrochem., 2013, 17(3), 891-897; DOI:10.1007/s10008-012-1939-5

19. Khalil S, Mikrochemica Acta, 2007, 158(3), 233-238; DOI:10.1007/s00604-0060706-7

20. Mohammed S K H and Shalaby N M, J Pharm Bio Sci., 2013, 4(1), 1037-1045.

21. Mohammed S K H, Al zahrani SS, Hussein Y M and Turkestani A I, Anal Chem An Indian J., 2014, 14, 201.

22. Reddy B P, Reddy K A, Reddy M S. Res Pharm Biotech., 2010, 2, 1-6

23. Gao W, Zhang Z, Li Z and Liang G, J ChromatogrSci., 2007, 45(8), 540-543; DOI:10.1093/chromsci/45.8.540

24. Farthing C A, Farthing D E, Koka S, Larus T, Fakhry I, Xi L, Kukreja R C, Sica D, and Gehr T W, J Chromatogr B Analyt Technol Biomed Life Sci., 2010, 878, 28912595; DOI:10.1016/j.jchromb.2010.07.022

25. Barot T G and Patel P K, J AOAC Int., 2010, 93, 516.

26. Mehanna M M, Motawaa A M and Samaha M W, J AOAC Int, 2012, 95(3), 1064-1068.

27. Gudipati E, Mahaboob S D, Nunna B R, Ashok K V and Rambabu K, Res Desk., 2012, 1, 66-73.

28. Meejung P and Suyoun A, J Forensic Sci., 2012, 57, 637-640; DOI:10.1111/j.15564029.2012.02164.x

29. Alivelu S, Santhosh P, Sowmya M, Sravanthi C and Nageshwar M, J Chem Pharm Res, 2013, 5(4), 315-318.

30. Prasanna R B, Amarnadh R K and Reddy M S, Res Pharm Biotechnol., 2010, 2, 1.

31. Kannappan N, Deepthi Y, Divya Y, Shashikanth S and Mannavalan R, Int J Chem Tech Res., 2010, 2, 329-333.

32. Sonawane P H, Panzade P S and Kale M A, Indian J Pharm Sci., 2013, 75(2), 230-233.

33. PatelJ K and Patel N K, Sci Pharm., 2014, 82, 749-763; DOI:10.3797/scipharm.1403-22

34. Aboul-Enein $\mathrm{H}$ Y and Ali I, Talanta, 2005, 65(1), 276-280; DOI:10.1016/j.talanta.2004.06.012 
35. Ramakrishna N V, Vishwottam K N and Puran S, J Chromatogr B Analyt Technol Biomed Life Sci., 2004, 809(2), 243-249.

36. Gratz S R, Flurer C L and Wolnik K A, J Pharm Biomed Anal., 2004, 36(3), 525-533; DOI:10.1016/j.jpba.2004.07.004

37. Jomoorthy K and Challa B R, Der Pharmacia Lettre, 2012, 4, 1401-1413.

38. Rodriguez F J, Berzas N J J, Castenada P G and Mora D N, J Chromatogr B Analyt Technol Biomed Life Sci., 2004, 811, 231-236; DOI:10.1016/j.jchromb.2004.07.016

39. Sunil Kumara A V V N K, Reddyb T V and Sekaranc C B, Anal Bioanal Chem Res., 2016, 3(1), 29-39.

40. El Sheikh R, Zaky M, Gouda A A and Abo Al Ezz S, J Chil Chem Soc., 2014, 59(1), 2248-2251; DOI:10.4067/S0717-97072014000100002

41. Abdel-Moety M M, Souaya E R and Soliman E A, J Pharm Pharm Sci., 2015, 4, 120.

42. Savjiyani N B and Patel P B, J Pharm Res., 2013, 3(5), 3652-3668.

43. Ahmed N R, Baghdad Sci J., 2013, 10(3), 1005.

44. Yunoos M, Sankar D G, Kumar B P and Hameed S, E J Chem,. 2010, 7, 833-836; DOI:10.1155/2010/630576

45. Fraihat S, Discovery, 2014, 22(73), 45-48.

46. Fraihat S, Int J Pharm Pharm Sci., 2014, 6, 443.

47. Kaf A A and Gouda A A, Chem Ind Chem Engin Quart, 2011, 17, 125-132.

48. Nesalin A J J, Babu J G C, Kumar V G and Mani T T, E J Chem., 2009, 6, 611-614; DOI:10.1155/2009/983146

49. Lakshmi V N, Kumar D R, Vardhan S V M and Rambabu C, Orient J Chem., 2009, 25, 791-794.

50. Anumolu P K D, Kavitha A, Durga D V, Bindu S H Sunitha G and Ramakrishna K, Anal Chem An Indian J., 2013, 13, 361-364.

51. Berka A, Vulterin J and Zyka J, Newer Redox Titrants, $1^{\text {st }}$ Ed., Pergamon Press, London, 1965; pp. 38.

52. Jeffery G H, Bassett J, Mendham J and Denney R C, Titrimetric analysis. In Vogel's a Text Book of Quantitative Inorganic Analysis, $5^{\text {th }}$ Ed., ELBS: London, 1989; p. 286.

53. Kolthoff I M, Belcher R, Stenger V A and Matsuyama G, Volumetric Analysis, III. Interscience Publishers, Inc., New York, USA, 1957, p. 504.

54. Amin A S, Ahmed I S, Dessouki H A and Gouda E A, SpectrochimActa A, 2003, 59, 695-703; DOI:10.1016/S1386-1425(02)00226-3

55. Amin A S, El Sheikh R, Mostafa M M, Gouda A A and Youssef E H, Inter J Pharm Pharm Sci., 2014, 6, 218.

56. Amin A S, Gouda A A and Youssef E H, Inter J Pharm Pharm Sci., 2014, 6, 247.

57. Gouda A A, Amin A S, El Sheikh R and Akl M A, Chem Ind Chem Eng Quar, 2010, 16, 11-18.

58. El Sheikh R, Amin A S, Gouda A A and Youssef A G, Pharm Anal Acta, 2013, 4, 1-9.

59. Morrison R T and Boyd R N, Organic Chemistry. $6^{\text {th }}$ Ed., New Jersey: Prentice-Hall, 2007, p.390.

60. Ringbom A, Z Anal Chem., 1939, 115, 332-343.

61. International Conference on Harmonisation of Technical Requirements for Registration of Pharmaceuticals for Human Use. ICH Harmonized Tripartite Guideline, Validation of Analytical Procedures: Text and Methodology Q2(R 1), Complementary Guideline on Methodology, London, November 2005.

62. Miller J N and Miller J C, "Statistics and Chemometrics for Analytical Chemistry" $5^{\text {th }}$ Ed., Prentice Hall, England, 2005. 